\title{
F.W.J. Schelling and the Rise of Historical Theology
}

Johannes Zachhuber

University of Oxford

Abstract: This article gauges the significance of Schelling's thought for the emergence of nineteenth century German, Protestant historical theology. The article first considers Schelling's relevant texts, mostly the System of Transcendental Idealism and the Lectures on University Studies. A second part looks at their theological readers considering in depth the early Philipp Marheineke and F. C. Baur. It becomes apparent that this reception occurs within intellectual networks consisting of individuals who are nowadays considered philosophers, historians, theologians or classicists, but who at the time participated in the same debates about history, mythology, speculation, and religion.

Key words: F.W.J. Schelling; Philipp Marheineke; Ferdinand Christian Baur; historicism; idealism; philosophy of history; historical theology; romanticism; mythology; religion

\section{Introduction}

In this paper, I propose to gauge the significance of Schelling's thought for the emergence of nineteenth century German, Protestant historical theology. The historical theology I have specifically in mind owes its existence to the broader turn to history or historicism that occurred in German intellectual culture at the beginning of the nineteenth century. As we shall see, this form of theology went way beyond the notion, wide-spread in Christian thought through the ages, that theology has a historical dimension, and instead aimed at the reconstruction of theology in its entirety as a historical discipline. This was only possible, however, because of the concomitant conviction that history, when fully understood, had its own religious and theological significance. Schelling clearly shared the latter belief. In his influential Vorlesungen über die Methode des akademischen Studiums (Lectures on University Studies, 1803), he explicitly committed to the dual imperative of a purely historical understanding of Christianity and a philosophical view of history that was in itself generated by the cultural and intellectual influence of this religion. In a section programmatically entitled The Historical Construction of Christianity, Schelling wrote this:

This is the great historical tendency of Christianity; this is the reason that the science of religion, in Christianity, is inseparable from history - is, indeed, one and the same with it. This synthesis with history, without which theology itself cannot even be conceived, presupposes, on the other hand, the higher Christian view of history. ${ }^{1}$

It is prima facie hardly surprising that this point of view would seem attractive to Christian theologians at a time when the general intellectual climate was so strongly influenced by the historical turn. Nevertheless, ascertaining the precise influence Schelling's concept had on historical theologians in the nineteenth century is difficult for more than one reason. Firstly, this influence cannot be assessed without taking into account the wider question of Schelling's significance for the rise of German historicism. Yet the latter is in itself complicated by the fact that in the course of the century, historicism morphed increasingly into a more positivist, anti-philosophical garb, and its main representatives therefore 
consciously or subconsciously sought to divert attention away from the debt their movement originally owed to speculative philosophers. To this date, therefore, historicism is often seen as a turn to the quasi-scientific study of history, and if mention is made of the relationship of its early representatives to the ideas of romanticism and idealism, this is only to emphasise how soon the movement left these eggshells behind. ${ }^{2}$

Secondly, nineteenth century historical theology as I have described it above, is still poorly understood; neither contemporary historians of theology nor historians of historiography have been perceptive of its place within the broader intellectual context of its time. ${ }^{3}$ While later historians sought to purge their academic ancestors from traces of speculative contamination thus neglecting their philosophical debt, their theological peers chose the opposite strategy discrediting early historicist theology on account of its speculative leanings. The work of F. C. Baur and his Tübingen School, arguably the main representatives of early historicist theology, is therefore usually written off even today as the illegitimate offspring of Hegelian idealism in historical theology.

Thirdly, the bifurcation of philosophy and history during the later nineteenth century has also led to a one-sided perception of idealist philosophers as speculative thinkers with no obvious relevance for those pursuing empirical research. Where their work has been appreciated more recently, this has been by philosophers or theologians who usually think of themselves as remote from historical work in the technical sense of the term. If therefore we are currently lacking a sufficiently accurate appreciation of the philosophical background to early nineteenth century historians and to the historicist background of theologians such as F. C. Baur, the same difficulty pertains to the potential relevance of Schelling's work for historical research. ${ }^{4}$

The present paper will not be able to remedy these three major gaps, but it would be wrong to discuss the narrower question of Schelling's influence on historical theology without taking into account the larger issues that remain unresolved in the background. I will therefore seek to reconstruct the part Schelling played in the emergence of nineteenth century historicist theology against the bigger picture of the early phase of historicism and the debt it owes to idealist philosophy and Schelling's in particular. To this end, I shall start from an account of Schelling's conception of history in a number of writings from the first decade of the nineteenth century. On this basis, his importance for historical theology will become apparent, and some light will hopefully be shone on the latter's place in early historicism as well.

\section{Schelling's view of history}

Given the complications of Schelling's intellectual development, it is important to stress right from the outset that the writings under consideration in the present paper all stem from a relatively brief period in his life, around the year $1800 .{ }^{5}$ At their centre is Schelling's System des Transcendentalen Idealismus, published in 1800, which contained a speculative theory of history. History, Schelling wrote there is the 'progressive, gradually self-disclosing revelation of the Absolute' ${ }^{6}$ In other words, it does not merely have meaning; it has absolute meaning. It is, one might say, God's own story whose eventual decipherment will therefore furnish humanity with perfect knowledge of itself. 
To justify this claim, Schelling observes that history is the 'union of freedom and necessity'. ${ }^{7}$ The conflict between the two initially arises at the level of the individual. Human beings understand themselves as citizens of two realms, the result of natural and spiritual (geistig) conditions at the same time. In good Kantian manner Schelling postulates that, while the former results in determinism, the latter requires freedom. Reflection about this tension subsequently leads beyond the individual, as the purpose of their actions 'can [ultimately] be realized, not by the individual alone, but only by the entire species' ${ }^{8}$ The problem of freedom and necessity thus recurs at the universal level of humanity and can therefore only be solved through an interpretation of history.

For Schelling, then, history is invoked to solve humanity's deepest problem, in his view the tension between its natural origin and its spiritual destiny. The answers it can provide take three basic forms, fatalism, atheism and religion. The first lays all the emphasis on determination and necessity; the second affirms only freedom; the third and most appropriate one suggests a synthesis of both. This religious view, according to which history bridges the tension of nature and spirit (Geist), produces a developmental account of history in three periods or stages which are dominated by the ideas of fate, nature and providence, respectively.

Yet while Schelling was thus clearly affirming a speculative philosophy of history, he was equally adamant that empirical history is not as such philosophical, but gains its value from its embrace of chance, coincidence, and even the arbitrary. He pushed this logic to its extreme point in an essay published in 1798 in which he sought to demonstrate the thesis that 'no philosophy of history is possible'. ${ }^{9}$ His argument: human beings can only have history insofar as it is not determined a priori; to the extent therefore that a philosophy of history is a construction of history a priori, it is impossible. ${ }^{10}$ Some scholars have concluded that this apparent contradiction indicates that Schelling's attitude to history is fundamentally ambivalent, but Christian Danz has recently shown that this is not necessarily the case. ${ }^{11}$ Whether or not Schelling can be altogether cleared of the charge of incoherence is not my direct concern here, but I propose that a closer look at his Lectures on University Studies (Vorlesungen über die Methode des akademischen Studiums) can shed further light on his position and, at the same time, explain its fascination for a whole generation of historical thinkers.

The idealistic framework of the Lectures, and specifically their indebtedness to the System of 1800 is beyond doubt. Schelling starts from the affirmation of the 'idea of knowing in and for itself unconditioned which is absolutely only one'. ${ }^{12}$ Its basis is the Absolute as the point of the identity of the Real and the Ideal, or being and knowledge. Human knowledge is described as an 'image' (Abbild) of this absolute knowledge; more individual sciences (Wissenschaften) form its organic parts. ${ }^{13}$ They thus jointly make up one, first philosophy which can be summed up as 'the effort to participate in archetypal knowing (Urwissen)' ${ }^{14}$ Total knowledge and the physical universe exist in perfect correspondence as the Ideal and the Real, but whereas the latter is subjected to finitude and determination, the former is the realm of infinity and freedom. ${ }^{15}$

In his later lectures, Schelling first addresses history in a section entitled The historical construction of Christianity. It begins with Schelling's general assertion that the particular 
scientific disciplines (Realwissenschaften) are set apart from philosophy by their historical dimension, another indication that history for him is firmly part of the empirical world. Yet he continues to emphasise a specific relationship that theology has with history:

Since it [sc. theology], as the true centre of the objective realization of philosophy, deals chiefly in speculative ideas, it is also the highest synthesis of philosophical and historical knowing. ${ }^{16}$

Theology, in other words, is singled out as the meeting ground of empirical history and speculative philosophy. The reason for this particular significance of theology does not so much lie in the fact that Christianity like all religions is historical in character and must therefore be understood from an historical angle. This tenet of enlightenment thought Schelling takes for granted. In addition, however, he perceives another, 'absolute relationship' between Christianity and history:

The absolute relation of theology is that in Christianity the world is looked upon as history, as the realm of morals, and that this general intuition constitutes its fundamental character. ${ }^{17}$

Christianity, Schelling claims, is not merely historical in an incidental sense, it is emphatically historical because it raises history to the level of the Absolute. While Greek religion was nature religion, Christianity is religion of the spirit, of morality, and thus of history. It is the religion in which 'the divine principle has ceased to reveal itself in nature, and is recognised only in history'. ${ }^{18}$

This special role Christianity has to play, according to Schelling, is due to its conception of the Incarnation: 'The highest religious feeling, expressed in Christian mysticism, holds the secret of Nature and the Incarnation of God for one and the same'. ${ }^{19}$ Schelling in this passage explicitly refers back to the System of 1800 and its three stages of history (nature, fate, and providence); Christianity, he emphasises, 'introduces this period of Providence as the prevailing mode of viewing the world - a mode which looks upon the world as history and as ruled by Providence.' 20

In this very concept of providence, Christianity resolves the tension between the arbitrary character of history and its relationship with the Absolute through which it partakes of necessity: in Christianity both religion and history converge in the perception of 'eternal necessity' grounded in the absolute. A view of history becomes possible here which permits a 'historicised' view of Christianity that does not, however, vitiate against its divine origin. As much as paganism was grounded in mythology, Christianity is founded on divine revelation. In practice, this means that Schelling calls the Church the symbolic perception of God as a 'living work of art' ${ }^{21}$ and calls for a speculative interpretation of Christian doctrine culminating in the assertion that the 'eternal Son of God' is 'the finite itself'. ${ }^{22}$

In conclusion, he summarises:

If Christianity, not only in itself, but in its most eminent forms, is historically necessary, and if we connect the higher view of history itself as an issue from the eternal necessity, then we 
have given the possibility of conceiving Christianity historically as a divine and absolute phenomenon, and, consequently, a truly historical science of religion or of theology. ${ }^{23}$

In the tenth lecture, Schelling finally turns to history, and in these reflections he once again emphasises its empirical character. While conceding that the 'highest' historical standpoint is the religious one, Schelling now denies that the latter is part of history stricte dictu:

This cannot be used in history as such, because it is not essentially different from the philosophical standpoint. Of course, it is evident that I do not deny either the religious or the philosophical construction of history; but the former is part of theology, - the latter belongs to philosophy, and is necessarily different from history as such. ${ }^{24}$

History in the narrower sense, then, belongs to the empirical realm and has two aspects: the collection and reconstruction of events; and their structural ordering under certain general principles. The latter, Schelling suggests, are often practical purposes which has led to the flourishing of 'pragmatic' histories - such as Polybius' and Tacitus' in antiquity and the more recent enlightenment historiographies. Schelling, however, is scathing in his dismissal of those attempts which, he argues, never reach history's universal dimension where it becomes the 'great mirror of the world-spirit' and the 'eternal poem of the Divine Mind'. ${ }^{25}$

What is this alternative? Ultimately, Schelling suggests history must rest on a 'synthesis of given facts and reality with the Ideal'. ${ }^{26}$ He hastens to add, however, that this cannot be achieved by means of philosophy 'since the latter rather abolished reality and is wholly ideal while history should be wholly actual, and at the same time ideal'. ${ }^{27}$

This (perfect union of actual and ideal) is nowhere possible except in art, which allows the actual to exist, as the drama admits real events or histories, but presents them in a complete form and in a unity whereby they become the expression of the highest ideas. Since it is by means of art that history, while it is the science of the actual, as such, is at the same time lifted above the actual to the higher realm of the ideal, to the level of science; accordingly the third and absolute stand-point of history is that of historical art. ${ }^{28}$

This, then, is Schelling's solution to the dilemma posed by the empirical task of the historian and the speculative need to integrate history into absolute knowledge. It is a solution that clearly is not free from internal tension, as Schelling on the one hand goes far in his affirmation of a quasi-theological, speculative philosophy of history while on the other, in his concern to safeguard the empirical work of the critical historian, he appeals to art as a better analogy for the way the historian combines empirical and constructive approaches. Does he then think of historical theology as a 'queen of history', so to speak? Or does he, rather, intend to create a safe space for 'secular' historians by drawing a clear boundary between their empirical or even 'artistic' work on the one hand and the speculations of philosophers and theologians on the other? Things hardly become clearer when on recalls that romantic theories of art frequently aligned it with religion, while theorists of religion, such as the early Schleiermacher, suggested an understanding of religion that is akin to our artistic sense (Kunstreligion). ${ }^{29}$ These issues will be relevant for understanding Schelling's reception, but at this point something else is more important: whatever the precise answer to these questions may be, there is but little doubt that the power of Schelling's message resulted from his affirmation of the need and the justification of critical, empirical, historical 
work while fully upholding the speculative dignity of history as a mirror of the world-spirit. It is this duality that underlies his impact on subsequent historical thought.

\section{Philipp Marheineke}

Philipp Marheineke is known today, if he is known at all, as a stalwart of Hegelian theology at the University of Berlin where he taught from 1811 until his death in 1846. It is, however, usually acknowledged that in the early 1800 s his initial philosophical influence was Schellingian. ${ }^{30}$ As we shall discover, however, the case is rather complex, certainly when it comes to Marheineke's contribution to historical theology. In 1806, Marheineke published the first volume of an ambitious project, a Universal Church History of Christianity. Only the first volume was ever to appear. Nonetheless, the work was sufficiently important for F. C. Baur to list it in his overview of Christian historiography (Epochen der Kirchengeschichtsschreibung), published in 1852, as a recent, major turning point. The first decade of the nineteenth century, Baur writes, was the period of transition from the subjectivity of Kantian-Fichtean idealism to the objectivity of Schelling's philosophies of nature and identity', ${ }^{31}$ and Marheineke's writing constituted a 'notable monument' of this development. ${ }^{32} \mathrm{His}$ book is thus singled out as showing particularly well that the more general impact Schelling's thought exercised during this period on nascent historicism affected the historiography of Christianity as well. It may be worth mentioning at this point that Marheineke sent the book to Friedrich Schleiermacher right after its publication, and it appears that the latter made us of it in his lectures on church history. ${ }^{33}$

Marheineke prefaces his work with a lengthy introduction, and it is in this part of his writing that he develops his ideas about historiography in general and church history in particular. He starts from postulating at the basis of history a duality of 'formless matter' and organising reason. The stuff from which history is made, he argues, is the pure multiplicity of atomised individuals. The particular in and of itself is 'a separated fragment'; the multitude of individuals constitutes only 'a formless aggregate of events and actions' ${ }^{34}$ No hierarchy, no value judgments are possible at this stage; no story line emerges. Human beings collect these details in chronicles but those are mere collections of details and certainly not yet histories. History, Marheineke remarks, should be no 'coin collection' (Münzkabinett) arranged on the basis of arbitrary similarities. ${ }^{35}$ Chance, he categorically asserts, is alien to true history whose laws result from the application of reason and intellect, from the arrangement of individual events as cause and effect. In this way, the historian ultimately realises an Idea that gives clarity and unity to the whole of history.

There are stages on this way, however. The first of them is critical research. Here, the historian attends to detail; his one and only criterion is 'faithfulness to historical truth'. ${ }^{36}$ In this process, the researcher is a servant to the historical material willingly giving up his freedom to subject himself to the object of his research. This clearly is a preliminary stage, but it is important to see here Marheineke's commitment to critical, empirical research, which has to be absolutely impartial. No knowledge of the whole is possible without specialist knowledge: 'truth about the totality is dependent on truth about the particular'. ${ }^{37}$

This 'realist' side of historiography must nonetheless be complemented by an 'ideal' side in which these observations are now subjected to the demands of the human intellect. Now the particular is taken into the service of the universal, and the historian turns from slave to 
master. He is creator and poet by virtue of the synthetic power of his spirit. Yet even this 'pragmatic' approach to history, Marheineke suggests, is not the final word as it merely considers history under the category of intelligibility and usefulness and thus stays close to the realities of the world. There is a further stage at which the historian turns into a true artist; he rises above the plurality of particular events and reaches their unity as the Idea itself: 'Thus the Absolute is found which not only no longer depends on anything else, but itself is the basis of all that is dependent; the principle and the spirit of history - religion.' ${ }^{\prime 38}$

Religion is the perspective from which, finally, history turns into providential order: 'God's eternal plan for the world is revealed in history as in a mirror'. ${ }^{39}$ For this reason, the true historian must be religious: 'religion is the basic note (Grundton) in the historiographer's soul' ${ }^{40} \mathrm{He}$ seeks to instil a similar sense in his readers. Such a religious view, Marheineke suggests, is needed for history in general, but in particular it is needed for church history, which is directly related throughout to the idea of the Holy while still occupied with events and developments in empirical history.

How much does this outline owe to Schelling? As we saw, Baur claimed the book as the most notable evidence of a Schellingian turn in Church History; intriguingly, he did not commit, however, to any direct dependence on Schelling's works. In fact, Schelling's name is nowhere mentioned in the Universalkirchengeschichte, nor are there unequivocal references to his writings. Marheineke's overall tendency is certainly close enough in spirit to Schelling's view of history in the System and the Lectures but any claim to direct dependence remains somewhat speculative.

The strongest parallel arguably is the notion of three stages of historiography: critical research, pragmatic and finally speculative history, as well as the connection of the latter with the notion of Idea and the Absolute. ${ }^{41}$ Reminiscent of Schelling is also the connection of speculative history with providence. Like Schelling, Marheineke calls the historian an 'artist', but it is less clear how seriously he takes this particular metaphor; 42 overall it appears that, where Schelling's conception led to the identification of history and art, Marheineke is keen to emphasise the ultimately theological character of speculative history. Absent from Marheineke, on the other hand, are Schelling's strong, somewhat perplexing assertions about the importance of chance and coincidence in history. On the contrary, the theological author emphatically claims that history must exclude chance. ${ }^{43}$

Marheineke's failure to mention Schelling cannot be explained by a general reluctance to mention contemporary authors as he refers to others including Adam Karl August von Eschenmayer and Friedrich Creuzer. Eschenmayer was at the time seen as part of Schelling's 'school' so a lengthy quote from one of his works arguably brought Marheineke in closer association with the master too. ${ }^{44}$ Creuzer's Historische Kunst der Griechen, published in 1803 , is cited with strong affirmation as well. ${ }^{45}$ Creuzer's remarkable work, the first modern history of Greek historiography, contains its own, brief theory of history which, at closer inspection, appears rather similar in conception and terminology to Marheineke's sketch. ${ }^{46}$

Creuzer's own intellectual background in the Historische Kunst was explored many years ago in a classical paper by Arnaldo Momigliano. The Italian historian postulated a philosophical proximity to Schelling, but conceded that he was unable 'to say how much Schelling meant 
to Creuzer in those years' ${ }^{47}$ Schelling, Momigliano argued, was the main force behind an attempt at the time to 're-establish the value of empirical history within the frame of the new idealism'. ${ }^{48}$ It would appear that this may be the most plausible conclusion for Marheineke too who clearly, as Baur rightly saw, belongs to a movement that had Schelling as its main spokesperson, but whose precise debt, in his conception of historical theology, to the philosopher from Swabia cannot be so easily ascertained.

\section{Ferdinand Christian Baur}

Ferdinand Christian Baur, undoubtedly the most important German, Protestant historical theologian of the former half of the nineteenth century, is still often characterised as a theological Hegelian. Yet while it is evident that major works written during the 1830 s and 40s reflect Baur's intellectual fascination, during this period, for the interpretation of religion espoused in Hegel's Lectures on the Philosophy of Religion published in 1832, there are at least two reasons warranting caution against a rash alignment of Baur with the Hegel School. Firstly, there is no evidence that Baur knew Hegel's thought until 1832, but by that time his intellectual formation was already well advanced as significant publications from the 1820 s show. Secondly, while Baur's philosophical judgments reveal his shifting allegiances over the decades, his views of history and of historical theology are arguably much more stable. In combination, the two considerations weaken considerably the case for a wholesale categorisation of Baur as a theological Hegelian. ${ }^{49}$

Towards the end of his life, Baur summarised his own life-long academic effort as a search for a coherent understanding of the historical process. Much painstaking research, he wrote, had provided to the scholarly community a wealth of historical detail; what was lacking, by comparison, was

... the intellectual processing and penetration of the whole material; the summation of the infinitely divided and manifold under the idea of its unity; the reduction of external appearances to their internal principle, which moves them and determines their interconnection; the construction of the development in which the various historical epochs and periods have taken their temporal course as moments of definitive conceptual unity. This task of research in church history drew my preference from the outset partly to the history of religion, [...] partly to the history of dogma. ${ }^{50}$

This programmatic statement tallies closely with the evidence from Baur's earliest work. His first, major publication was a two-volume treatment of Symbolik und Mythologie (1824/25). The subtitle of the study, however, betrays Baur's ultimate interest to be a study of the mythological world in order to illuminate 'the nature religion of antiquity'. ${ }^{51}$ His work is essentially an attempt to describe and systematise the history of religion prior to the emergence of Christianity - precisely that first half which, according to Schelling, was characterised by the alignment of religion with the concept of nature. ${ }^{52}$

In his preface to the work, Baur made it furthermore clear that the objective stated in his much later work was indeed at the heart of his research even at this early point. Mythology, he wrote, attracted him in the hope that it would further his understanding of 'the idea of the unity of all knowledge' which is prefigured in the 'organism of human intellect'. ${ }^{53}$ The more he studied it, the more he became convinced that it was 'not merely an arbitrary aggregate of atoms that had somehow been conjoined together'. ${ }^{54}$ On the contrary, 
mythology when seen in its coherence reveals a philosophy that stands above the individual philosophical systems the same way 'the genus stands above the individual'. Since world history is 'a revelation of the deity', it can be fully understood only as an emergent consciousness which is neither that of an individual nor even that of a nation, but that of humanity as a whole 'whose living unity is the image and the mirror of the divine Spirit'. ${ }^{55}$

The best hope for a reconstruction of this unity, Baur continues, rests on the identification and the scrutiny of the point of origin, 'the living spring' from which all other expressions of the spirit flow; this is the history of religious faith. ${ }^{56}$ Mythology is thus part of the history of religion; more precisely, it is the one part that is characterised by its opposition to Christianity, which is the religion of divine revelation. He goes on to protest against those who advocate a principal restriction of the history of religion to that of one single nation. ${ }^{57}$ In this way, he warns, the 'intimate connection' between philosophy and history that is particularly evident in mythology, will inevitably be obscured. It is the Idea, he insists, that determines individual expressions; 'without the idea of religion, the essence of individual forms of religion cannot be understood' ${ }^{58}$ Science (Wissenschaft) must therefore ultimately choose between one of two ways:

[...] either that of separation and isolation, which, consistently pursued, necessarily leads to atomism, fatalism and atheism, or that on which dawns a purer and higher consciousness of the divine to the degree to which the spiritual life of the peoples is recognised in its great interconnectedness as a great whole, thus leading to an ever more sublime idea of the divine. [...] I am not scared of the well-worn charge of mixing philosophy and history. Without philosophy, history for me remains forever dead and dumb. ${ }^{59}$

Baur here follows quite clearly in the footsteps of Marheineke's approach to the history of religion with its strong emphasis on the need to work out the unity of historical phenomena and the insistence that this unity is in and of itself religious. At the same time, echoes of Schelling's language in the System and the Lectures are much stronger than in Marheineke. ${ }^{60}$ We know that Baur read the System as a young man; it is possible that he was encouraged in this interest by Eschenmayer's lectures Über einen Grundriss der Philosophie, besonders der neueren which he attended in $1812 .{ }^{61}$ In 1822 , he wrote a letter advising a younger friend during his philosophical studies. While cautioning against Fichte, Baur warmly recommended Schelling and in particular the System, 'a writing I very much liked'. ${ }^{62}$ In the present text, Baur's insistence on the 'idea of the unity of knowledge' and its analogous relationship to the organic unity of the human mind is taken straight from Schelling's Lectures and so is his notion of a division of religious history into pre-Christian mythology and Christian revelation. That history as a whole is God's revelation, on the other hand, is an almost literal allusion to the System.

It would, however, be wrong to see Baur's emphasis entirely on the synthetic and idealistic side of Schelling's view of history. In fact, he complains that Marheineke's theory was insufficient precisely because of the vagueness of his idealism. The idea, Baur writes,

[...] only soars above the sphere of phenomena with which it ought to be connected, not entering into an inner, immanent relationship with those phenomena; and there thus remains an unfilled void between it and the life of history whose moving principle it ought to be. ${ }^{63}$ 
This same sentiment subsequently underlies Baur's attempt to sketch his own understanding of the task of church history as he offers it in the final chapter of his Epochen der Kirchengeschichtsschreibung, published in 1852. In fact, he characterises the current desiderata of historical research in almost the same words that he had employed for Marheineke's work. The idea 'soars indefinitely and at a great distance' above the phenomena with which it should be connected.

It is not yet strong and vital enough to penetrate and vivify the historical material as the soul penetrates the body, or to become, through such an organic unity, the moving principle of the entire series of phenomena in which the history of the Christian church takes its course. $^{64}$

How can this be changed? Baur proposes a closer look at the history of the church; understood as an idea, he argues, it leads directly to certain periodisations, chiefly by means of the watershed that is the Reformation. ${ }^{65}$ Why is periodisation so important? Evidently, Baur felt that it was the most obvious way in which a general, overarching idea could be seen as directly interacting with the detailed historical material.

Right at the outset of this final, concluding chapter of the book, Baur adds to his text a long footnote in which he gives several extensive quotations from Schelling's Lectures in unmitigated support of his own view. The next, necessary step in the development of church history, as envisaged by himself, is identical, Baur suggests, to Schelling's proposal of a development beyond 'transcendental' and 'pragmatic' historiography. This is backed up with direct citations from Schelling's tenth lecture culminating in the following assertion:

History does not become complete enough to satisfy Reason until the empirical causes that satisfy the understanding are used as tools and means of the manifestation of a higher necessity. In such a presentation, history cannot lack the effect of the greatest and most wonderful drama, - a poem conceived by an Infinite Mind. ${ }^{66}$

'And where', Baur adds, 'should [history] have lacked this effect least than in the field of church history'? ${ }^{67}$ These words, written, apparently, almost exactly 50 years after the publication of Schelling's Lectures, are the most explicit evidence so far that Schelling's concept was important to the pioneers of historicist theology. Admittedly, the significance of this observation could be queried because of the lateness of the reference. Baur, it might be objected, merely compares his own agenda to Schelling's after the fact; he stipulates this parallel at the end of his life rather than acknowledge an influence early in his career.

Yet there are reasons to be more sanguine about the importance of the citation. Firstly, as we have seen Baur's views on the principles on historiography and its empirical and philosophical aspects seem surprisingly stable during the decades of his scholarly life. Secondly, parallels with Schelling's approach were clearly visible, albeit unacknowledged, in Baur's Symbolik und Mythologie. And finally, there seems no reason why Baur would conjure up Schelling in 1852 to justify a programme he had been pursuing for decades unless there was a clear relation between Schelling's thoughts on history and his own scholarly impetus. 
There is then reason to believe that Baur - as Marheineke before him - adopted as exemplary Schelling's tripartite division of historiography - critical-empirical; pragmatic; speculative - with a specific emphasis on the need for the last of those which, the historical theologians insisted, was the history of religion and as such, in effect, a kind of philosophical-historical apologetic for Christianity. This, of course, was a somewhat onesided reading of Schelling's theory. As we have seen, in the context of the tenth lecture Schelling was keen to reject the idea that history, even in its fullest realisation, was philosophical let alone theological. Instead, he proposed the analogy between history and art. Intriguingly, the relevant passage - perhaps the single most well-known statement from Schelling's tenth lecture - would have been right at the heart of Baur's string of quotations from the work, - except that Baur omitted it. This is striking, but cannot surprise: Baur could refer to Schelling's theory as expressed in the tenth of his Lectures only by making a small but crucial change. While for Schelling history was not philosophy and therefore culminated in the notion of the history as art, Baur saw history as completed in a form of speculation based on the philosophy of religion. For this, admittedly, he could draw on other texts by the philosopher, such as the eighth lecture On the Historical Construction of Christianity. But while it is hard to believe that Baur was not swayed by this particular logic - and to show this in detail would require a much wider investigation than is possible here ${ }^{68}$ - there is no evidence that he ever claimed its support for his own vision of historical theology.

Ultimately, for Baur too the question of influences may turn out to be complex. In an important study of Baur's position in nineteenth century historicism, Klaus Scholder drew attention to Wilhelm von Humboldt's famous lecture Über die Aufgabe des Geschichtsschreibers (1821) as a possible source for Baur's understanding and practice of history. ${ }^{69}$ His overall aim was to inscribe Baur into the broader development in German historicism connected with names such as Barthold Georg Niebuhr and Leopold von Ranke. Humboldt, whose influence on Ranke is well established, seemed attractive as a common link. This is not the place to investigate in detail the merits and problems of Scholder's argument which is in itself speculative as Baur nowhere mentions von Humboldt's lecture. More important, however, is another point. Humboldt's concept too has been traced back to Schelling's ideas in the Lectures and the System, ${ }^{70}$ and the parallels are indeed rather striking. Baur's putative debt to von Humboldt may thus in reality have been a debt to Schelling, but it is equally possible that Schellingian ideas were, at least partly, mediated to him via von Humboldt.

What therefore emerges is the existence of close intellectual networks in which theological, philosophical, historiographical, and other currents were closely and perhaps inextricably intertwined at the time. In this climate, history could be aligned with art or with philosophy or religion; but art could also be aligned with religion or philosophy; and again philosophy with religion and so forth. This does not mean that the quest for intellectual influences and interrelations becomes meaningless; on the contrary, it is imperative better to understand how problematic more recent disciplinary divisions have rendered our perception of intellectual lineage in early nineteenth century intellectual culture. Baur, Marheineke and Schelling, in different ways, exemplify this very difficulty insofar as contemporary interest in their work is usually restricted to their 'discipline', which stands in the way of a proper appreciation of their intellectual contributions as much as it may enhance it. 
It does mean, however, that a joint-up study of early historicism, especially on the theological side, will probably never arrive at an unequivocal affirmation of one single person's influence that can explain everything. Schelling, so much should by now be clear, was immensely important for both the early Marheineke and for Baur. It is probable, moreover, that other influences were indirectly Schellingian too: Baur may well owe more to Marheineke's Universalkirchenhistorie than he lets on, but ideas he found there could have originated in Schelling. Marheineke in turn may have been stimulated by Creuzer's reflections in the Historische Kunst der Griechen, which for one reason or another were ultimately similar to Schelling's ideas in his Lectures on University Studies. And if it is true that Baur was inspired by Humboldt's lecture on the task of the historian, he would have encountered Schelling's ideas there as well.

\section{Conclusion}

Compared to its title, this paper has been somewhat modest in its scope. In order to gauge Schelling's significance for nineteenth century historical theology, I have focussed on two of its representatives, the young Philip Marheineke and F. C. Baur. There would obviously be others who deserve to be studied in the same context, such as Schleiermacher, de Wette or the younger members of the Tübingen School. Also significant is his reception by Catholic thinkers such as Johann Adam Möhler. ${ }^{71}$ Further, the historical movement in nineteenth century theology was not over with this generation of scholars but continued to the end of the century and beyond. The case can be made that the later forms of theological historicism, from Albrecht Ritschl to Adolf Harnack and Ernst Troeltsch, are not as detached from their forerunners in the former half of the century as one might think. To the extent that they all affirmed the notion that critical historiography had to go together with theological and possibly philosophical interpretation, these later thinkers are still part of the movement that began at the turn of the nineteenth century. Ernst Troeltsch, at least, was fully conscious of this historical background. ${ }^{72}$

Within these limitations, however, four main insights should have emerged from my account. Firstly, Marheineke and Baur both show the underlying concern of a novel type of historical theology emerging at the time. They sought to move the study of church history beyond the critical and pragmatic historiography of the late eighteenth century onto a form that aligns it with both theology and history. Crucial for this ambitious project was a view of history encompassing the critical study of documents and sources as well as their interpretation on the premise that, when perceived in its total coherence, history became transparent for the divine. Yet for history to result in this speculative insight, it had to be read and studied from a religious point of view, more specifically a Christian point of view. This need for true historians to be religious was not, however, understood as imperilling their impartiality. On the contrary, they will be keen to affirm the strict need to be as objective and critical in their study as possible. The significance of their faith lies at the level of speculative insight; it was, we might say, a hermeneutical necessity.

Secondly, in this attempt the historical theologians were part of the broader historicist movement of their time, and in many ways their work needs to be contextualised with the contemporaneous efforts of figures such as Niebuhr, von Humboldt, Creuzer, and others. Yet there are differences. One way of expressing them might be to say that the theological historians have a clear apologetic interest. For them, the study of history does not simply 
lead to a vaguely religious level; it ultimately confirms their conviction that Christianity is the absolute religion and Protestantism its supreme realisation. This difference is clearly articulated at the time and was later increasingly seen as a bifurcation between a 'faithbased' theological historiography and a modern, secular one. From today's perspective, however, one may perhaps query whether the value judgment implied in this distinction is not in itself problematical. The various ideological premises of all romantic and historicist thinkers appear so evident to us that we can perhaps begin to appreciate the relative honesty of the theologians who were at least willing to admit where they found their ultimate motivations.

Thirdly, Schelling, more specifically his System and the Lectures, was of major significance for the emergence of this novel form of (Protestant) historical theology. This is true even if it has also become evident that his influence is often difficult to ascertain with absolute precision as it is diverted and refracted on account of the protagonists' participation in wider intellectual networks. The fundamental impulse, so much seems clear, was his attempt to give philosophical justification to a version of historiography that (1) took seriously critical study; (2) affirmed the need to synthesise these findings to achieve truly meaningful insight; (3) privileged speculative over pragmatic aims. Ultimately, the clearest evidence in both Marheineke and Baur of Schelling's thought was their adoption of this impulse in the form of three stages or types of historiography: critical, pragmatic, and speculative. This vision, it appears, was immensely powerful and exerted a strong influence on a wide variety of thinkers who passed it on to others (and perhaps to each other as well). As we saw, F. C. Baur affirmed it even in his last years, long after the world's fascination for idealist philosophy had come to an end.

Fourthly and finally, there were clear differences in the way Schelling's ideas were received. Perhaps the single most influential concept for nascent historicism more generally was the idea of history as art which was adopted by Creuzer, von Humboldt and many others. Yet the theological historians eschewed it. This was most strikingly evident in Baur who omitted the relevant sentence from a longer passage he quoted verbatim from the Lectures, but the situation in Marheineke was similar. Schleiermacher, incidentally, singled this idea out for particularly sharp criticism in his review of Schelling's Vorlesungen. ${ }^{73}$ Instead, Schelling's theological readers complemented the threefold scheme by reference to a religious history which connects the historical with the absolute. It was this modification that ultimately underwrote a version of paradigmatically historical theology based on the union of critical historiography with speculative reflection.

Bibliography

Albrecht, Christian. Historische Kulturwissenschaft neuzeitlicher Christentumspraxis: Klassische Protestantismusdeutungen in ihrer Bedeutung für das Selbstverständnis der Praktischen Theologie. Tübingen: Mohr Siebeck, 2000.

Baur, Ferdinand Christian. Briefe. Teil 1: Die frühen Briefe (1814-1835), ed. Carl E. Hester. Sigmaringen: Thorbecke, 1993.

Baur, Ferdinand Christian. Epochen der kirchlichen Geschichtsschreibung, Tübingen: Fues, 1852. English Text: Ferdinand Christian Baur on the Writing of Church History. Translated by Peter C. Hodgson. New York: OUP, 1968. 
Baur, Ferdinand Christian. Geschichte der christlichen Kirche, vol 2: Die christliche Kirche vom Anfang des vierten bis zum Ende des sechsten Jahrhunderts in den Hauptmomenten ihrer Entwicklung. 2nd ed. Tübingen: Fues, 1863.

Baur, Ferdinand Christian. Symbolik und Mythologie oder die Naturreligion des Alterthums. 2 vols. (vol. 2 in 2 parts). Stuttgart: Metzler, 1824-25.

Bowie, Andrew. Schelling and Modern European Philosophy: An Introduction. London: Routlegde, 1993.

Creuzer, Friedrich. Die historische Kunst der Griechen in ihrer Entstehung und Fortbildung. Leipzig: Göschen, 1803.

Danz, Christian. "Geschichte als fortschreitende Offenbarung Gottes: Überlegungen zu Schellings Geschichtsphilosophie." In: System als Wirklichkeit: 200 Jahre Schellings "System des Transzendentalen Idealismus", edited by Christian Danz, Claus Dierksmeier, and Christian Seysen. 69-82. Würzburg: Königshausen \& Neumann, 2001.

Eschenmayer, Carl A. Der Eremit und der Fremdling: Gespräche über das Heilige und die Geschichte. Erlangen: Walther, 1805.

Gerber, Simon. Schleiermachers Kirchengeschichte. Tübingen: Mohr Siebeck, 2015. Hester, Carl. "Gedanken zu Ferdinand Christian Baurs Entwicklung als Historiker anhand zweier unbekannter Briefe." Zeitschrift für Kirchengeschichte 84 (1973): 249-269. Hodgson, Peter Crafts. The Formation of Historical Theology: A Study of Ferdinand Christian Baur. London: Harper and Row, 1966.

Howard, Thomas Albert. Religion and the Rise of Historicism: W.M.L. de Wette, Jacob Burckhardt, and the Theological Origins of Nineteenth Century Historical Concsiousness. Cambridge: CUP, 2000.

Humboldt, Wilhelm von. "Über die Aufgabe des Geschichtsschreibers" (1821). In Schriften zur Anthropologie und Geschichte. Vol. 1 of Werke in fünf Bänden, edited by Andreas Flitner and Klaus Giel. 4th edition. Darmstadt: WBG, 2002, 585-606.

Iggers, Georg G. From Historicism to Postmodernity: From Scientific Objectivity to the Postmodern Challenge. Hanover, N.H.: Wesleyan, 1997.

Iggers, Georg G. The German Conception of History: The National Tradition of Historical Thought from Herder to the Present. Revised edition. Hanover, N.H.: Wesleyan, 1983. Jantzen, Jörg. "Eschenmayer und Schelling: Die Philosophie in ihrem Übergang zur Nichtphilosophie." In: Der Streit um die göttlichen Dinge (1799-1812), edited by Walter Jaeschke, 74-97. Hamburg: Meiner, 1999.

Marheineke, Philipp. Universalkirchenhistorie des Christenthums, Erlangen: Palm, 1806. Momigliano, Arnaldo. "Friedrich Creuzer and Greek Historiography." Journal of the Warburg and Courtauld Institutes 9 (1946), 152-63.

O'Meara, Romantic Idealism and Roman Catholicism: Schelling and the Theologians, South Bend, IN: Notre Dame University Press, 1982.

Rohls, Jan. "Schelling and Protestant Theology." International Journal of Philosophy and Theology (this issue).

Schelling, Friedrich Wilhelm Joseph. Allgemeine Übersicht der neuesten philosophischen Literatur (1798). In: Sämmtliche Werke, edited by K. F. A. Schelling. Vol. I/4, 179-190.

Stuttgart: Cotta, 1859.

Schelling, Friedrich Wilhelm Joseph. System des transcendentalen Idealismus (1800). In: Sämmtliche Werke, edited by K. F. A. Schelling. Vol. 1/3, 327-634. Stuttgart: Cotta, 1858. English Text: System of Transcendental Idealism. Translated by Peter Heath. Charlottesville, VA: University of Virginia Press, 1978. 
Schelling, Friedrich Wilhelm Joseph. Vorlesungen über die Methode des akademischen Studiums (1803). In: Sämmtliche Werke, edited by K. F. A. Schelling. Vol. I/5, 207-311. Stuttgart: Cotta, 1859. English text: Lectures on University Study. Translated by Ella S. Morgan. The Journal of Speculative Philosophy 11 (1877), 92-100, 160-177, 225-244, 363370; 12 (1878), 205-213; 13 (1879), 190-198, 310-319; 14 (1880), 145-153; 15 (1881), 1-8, 152-158.

Schleiermacher, Friedrich Daniel Ernst. "Rezension von Friedrich Wilhelm Joseph Schelling: Vorlesungen über die Methode des akademischen Studiums (1804).“ In: Schriften aus der Stolper Zeit, edited by Eilert Herms, Günter Meckenstock, and Martin Pietsch. Vol. I/4 of Kritische Gesamtausgabe. Berlin: de Gruyter, 2002, 461-484.

Scholder, Klaus. "Ferdinand Christian Baur als Historiker." Evangelische Theologie 21 (1961), 435-458.

Scholz, Gunter. "Schleiermacher und die Kunstreligion." In: 200 Jahre "Reden über die Religion": Akten des 1. Internationalen Kongresses der Schleiermacher-Gesellschaft. Halle, 14.-17. März 1999, edited by Ulrich Barth and Claus-Dieter Osthövener, 515-533. Berlin: de Gruyter, 2000.

Spranger, Eduard. "Wilhelm v. Humboldts Rede 'Über die Aufgabe des Geschichtschreibers' und die Schellingsche Philosophie." Historische Zeitschrift 100 (1908), 541-563.

Zachhuber, Johannes. Theology as Science in Nineteenth Century Germany: From F. C. Baur to Ernst Troeltsch. Oxford: OUP, 2013.

\section{Note on the Contributor}

Johannes Zachhuber is Professor of Historical and Systematic Theology at the University of Oxford, and Fellow and Tutor of Theology at Trinity College, Oxford. He obtained a DPhil in Theology at Oxford in 1997 and subsequently taught at Humboldt University in Berlin, Germany. He took up his current post in 2005. His has published widely on nineteenth century Christian thought, notably Theology as Science in Nineteenth Century Germany: From F.C. Baur to Ernst Troeltsch (Oxford 2013). He is an editor of the Oxford Handbook of Nineteenth Century Christian Thought (Oxford 2017). Another major research interest is the history of Christian thought in late antiquity and its relationship with ancient philosophy.

\footnotetext{
${ }^{1}$ Schelling, Vorlesungen, 291; English text (=ET): 209.

${ }^{2}$ Iggers, German Conception; Historicism.

${ }^{3} \mathrm{Cf}$. however Hodgson, Formation; Howard, Religion.

${ }^{4}$ Schelling's contribution to the philosophy of history, however, has been studied. See Danz,

"Geschichte." I must leave to one side in this article the question of the various influences on Schelling's interest in history and his conception of it.

${ }^{5}$ On Schelling's development cf. Bowie, Schelling, 12-14.

${ }^{6}$ Schelling, System, 603; ET: 211.

${ }^{7}$ Ibid., 593; ET: 203.

8 Ibid., 596; ET: 205.

${ }^{9}$ Schelling, Allgemeine Übersicht, 183.

${ }^{10}$ Ibid., 190.

${ }^{11}$ Danz, "Geschichte," esp. 70.

${ }^{12}$ Schelling, Vorlesungen, 215; ET: 95.

13 Ibid., 216-217.

${ }^{14}$ Ibid., 218; ET: 97.
} 
15 Ibid.

16 Ibid., 286; ET: 205.

17 Ibid., 287; ET: 206.

18 Ibid., 289; ET: 208.

19 Ibid., 290; ET: 209.

$20 \mathrm{lbid}$.

21 Ibid., 293; ET: 212.

22 Ibid., 294; ET: 213.

23 Ibid., 295.

24 Ibid., 307; ET: 311.

25 Ibid., 309; ET: 312.

${ }^{26}$ Ibid., 309; ET: 313.

27 Ibid.

28 Ibid., 309-10; ET: 313.

${ }^{29}$ Scholz, "Schleiermacher".

${ }^{30}$ E.g. Rohls, "Schelling," ??; Gerber, Schleiermachers Kirchengeschichte, 91.

${ }^{31}$ Baur, Epochen, 198, ET: 203.

32 Ibid.

${ }^{33}$ Gerber, Schleiermachers Kirchengeschichte, 91-95.

${ }^{34}$ Marheineke, Universalkirchenhistorie des Christentums, 8.

35 Ibid.

36 Ibid., 9.

37 Ibid., 10.

38 Ibid., 13.

39 Ibid., 14.

40 Ibid., 15.

${ }^{41}$ Note however that in Schelling the speculative 'true history' is more a critique of the pragmatic approach whereas Marheineke seems to think that the latter is a legitimate, albeit imperfect, 'stage' of historical work. Cf. Schelling, Vorlesungen, 308-9 and Marheineke, Universalkirchenhistorie des Christentums, 12.

${ }^{42}$ Marheineke, Universalkirchenhistorie des Christentums, 13.

43 Ibid., 8.

${ }^{44}$ Ibid., 15-6. His citation is from Eschenmayer, Eremit. On Eschenmayer and Schelling see Jantzen, "Eschenmayer und Schelling."

${ }^{45}$ Marheineke, Universalkirchenhistorie des Christentums, 16.

${ }^{46}$ Creuzer, Historische Kunst, esp. 226-232.

${ }^{47}$ Momigliano, "Friedrich Creuzer," 159.

48 Ibid.

${ }^{49}$ Albrecht, Historische Kulturwissenschaft, 75-7.

${ }^{50}$ Baur, Geschichte, vi.

${ }^{51}$ Baur, Symbolik und Mythologie.

52 Schelling, Vorlesungen, 292.

${ }^{53}$ Baur, Symbolik und Mythologie, 1, iv.

54 Ibid., v.

55 Ibid., vi.

56 Ibid.

57 Ibid., $x$. 
58 lbid.

${ }^{59}$ Ibid., xi.

${ }^{60}$ On Schelling's influence on Baur see Hester, "Gedanken."

61 Hester, "Gedanken," 254.

62 Baur, Briefe, 26-27.

${ }^{63}$ Baur, Epochen, 200; ET: 205.

${ }^{64}$ Ibid., 247-8; ET: 241 (with changes).

65 Ibid., 249.

${ }^{66}$ Ibid., 249 = Schelling, Vorlesungen, 310; ET: 314.

67 Baur, Epochen, 249; ET: 242 (with changes).

${ }^{68}$ See also my account of Baur's thought in Zachhuber, Theology as Science, 25-72.

${ }^{69}$ Scholder, "Ferdinand Christian Baur," 444-445; Humboldt, "Über die Aufgabe."

70 Spranger, "Wilhelm v. Humboldts Rede."

71 O'Meara, Romantic Idealism.

72 Zachhuber, Theology as Science, 284-285.

${ }^{73}$ Schleiermacher, "Rezension," 475. 